\title{
The effect of allicin on cell proliferation and apoptosis compared to blank control and cis-platinum in oral tongue squamous cell carcinoma
}

OncoTargets and Therapy

\author{
Yanjun Guo' \\ Hongli Liu ${ }^{2}$ \\ Yong Chen' \\ Wei Yan' \\ 'Department of Oral and Maxillofacial \\ Surgery, Cangzhou Central Hospital, \\ Cangzhou, People's Republic of China; \\ ${ }^{2}$ School of Stomatology, Cangzhou \\ Medical College, Cangzhou, People's \\ Republic of China
}

Background: Oral tongue squamous cell carcinoma (OTSCC) has aggressive clinical behavior with poor prognosis. Allicin plays a tumor-suppressive role in various cancers, although the role of allicin in OTSCC is unknown. We aimed to investigate the effect of allicin on cell proliferation and apoptosis compared to blank control and cis-platinum in OTSCC.

Methods: Tca- 8113 and SCC- 25 cells were treated with non-stimulated control, $12.5 \mu \mathrm{g} / \mathrm{mL}$ allicin, $25 \mu \mathrm{g} / \mathrm{mL}$ allicin, $50 \mu \mathrm{g} / \mathrm{mL}$ allicin, and $40 \mu \mathrm{g} / \mathrm{mL}$ cis-platinum, which were divided into blank control, allicin $12.5 \mu \mathrm{g} / \mathrm{mL}$, allicin $25 \mu \mathrm{g} / \mathrm{mL}$, allicin $50 \mu \mathrm{g} / \mathrm{mL}$, and cis-platinum $40 \mu \mathrm{g} / \mathrm{mL}$ groups, respectively. Cell proliferation was determined by the Cell Counting Kit- 8 assay. Cell apoptosis was detected by annexin V/propidium iodide and Western blot assays. Results: In Tca- 8113 and SCC- 25 cells, cell proliferation was inhibited by $40 \mu \mathrm{g} / \mathrm{mL}$ cisplatinum, $12.5 \mu \mathrm{g} / \mathrm{mL}$ allicin, $25 \mu \mathrm{g} / \mathrm{mL}$ allicin, and $50 \mu \mathrm{g} / \mathrm{mL}$ allicin. Cell apoptosis was promoted by $40 \mu \mathrm{g} / \mathrm{mL}$ cis-platinum, $12.5 \mu \mathrm{g} / \mathrm{mL}$ allicin, $25 \mu \mathrm{g} / \mathrm{mL}$ allicin, and $50 \mu \mathrm{g} / \mathrm{mL}$ allicin, while compared to $40 \mu \mathrm{g} / \mathrm{mL}$ cis-platinum, it was increased by $50 \mu \mathrm{g} / \mathrm{mL}$ allicin. Western blot assay revealed that expression of pro-apoptosis protein Bax and C-Caspase 3 increased, but apoptosis-inhibitory protein Bcl-2 expression decreased with $40 \mu \mathrm{g} / \mathrm{mL}$ cisplatinum, $12.5 \mu \mathrm{g} / \mathrm{mL}$ allicin, $25 \mu \mathrm{g} / \mathrm{mL}$ allicin, and $50 \mu \mathrm{g} / \mathrm{mL}$ allicin, while compared to $40 \mu \mathrm{g} / \mathrm{mL}$ cis-platinum, Bax and C-Caspase 3 expression was increased by $50 \mu \mathrm{g} / \mathrm{mL}$ allicin. Conclusion: Allicin was shown to have good efficacy in repressing cell proliferation as well as facilitating cell apoptosis in OTSCC.

Keywords: allicin, cell proliferation, cell apoptosis, cis-platinum, OTSCC

\section{Introduction}

Oral cancer, a malignant neoplasia which arises on the lip or oral cavity, is considered the eighth most common carcinoma worldwide, with an estimated 354,862 new cases and 177,384 deaths occurring during 2018 in 185 countries. ${ }^{1}$ As the most common type of oral cancer, oral tongue squamous cell carcinoma (OTSCC) is characterized by fast growth, strong infiltration, high rates of metastasis, and aggressive clinical behavior, with a relatively poor prognosis, and the global incidence of this disease is continuing to increase. ${ }^{2,3}$ In clinical practice, chemotherapy has been widely applied in OTSCC patients. Cis-platinum-based chemotherapy is frequently utilized for OTSCC treatment and has great efficacy in killing cancer cells and inhibiting tumor growth to improve therapeutic
Correspondence: Yanjun Guo Department of Oral and Maxillofacial Surgery, Cangzhou Central Hospital, 16 West Xinhua Road, Cangzhou 06I00I, People's Republic of China

Tel +86 3172075544

Fax +86 3172075544

Email GuoyanjunII7@I63.com 
outcomes; however, several adverse effects are related to cis-platinum-based chemotherapy (including pain, nausea, and vomiting), which decrease the quality of life and result in poor outcomes in some OTSCC patients. ${ }^{4}$ In addition, some OTSCC patients have been reported to gradually develop drug resistance to cis-platinum, which directly leads to worse therapy outcomes, high recurrence rates, or even death. ${ }^{5}$ According to a previous study, tumor biomarkers are associated with the tumorigenesis and progression of various cancers, such as breast cancer. ${ }^{6}$ Therefore, there is a need to explore additional and convincing treatment drugs or tumor biomarkers to improve the efficacy of therapy in OTSCC patients.

Allicin, a natural diallyl trisulfide compound isolated from traditional food and medicinal garlic, is widely known for its multiple pharmacological effects, especially its anti-tumor effect $^{7}$ Several studies suggest that allicin can inhibit cell proliferation, hinder cell migration, and enhance cell apoptosis in various cancers, including colorectal cancer, liver cancer, and human renal clear cell carcinoma, while the role of allicin in OTSCC cells is scarcely known. ${ }^{7-9}$ Therefore, we aimed to investigate the effect of allicin on cell proliferation and cell apoptosis compared to a blank control and cis-platinum in OTSCC.

\section{Methods}

\section{Cell culture}

The Tca-8113 cell line was purchased from the Cell Bank of the Chinese Academy of Sciences (Shanghai, People's Republic of China). The SCC-25 cell line was a gift from Shanghai Jiao Tong University School of Medicine (Shanghai, People's Republic of China). Tca-8113 was from tongue squamous cell carcinoma and established from the biopsy of a squamous cell carcinoma of the tongue, and SCC25 cells were from squamous cell carcinoma and established from the biopsy of a squamous cell carcinoma of the tongue of a 70-year-old man. Both of these cell lines were the third generation when they were utilized. After resuscitation, Tca8113 cells were cultured in $80 \%$ Roswell Park Memorial Institute (RPMI) 1640 (Gibco, Thermo Fisher Scientific, Waltham, MA, USA) medium that was supplemented with $1.5 \mathrm{~g} / \mathrm{L} \mathrm{NaHCO}{ }_{3}, 2.5 \mathrm{~g} / \mathrm{L}$ glucose, $0.11 \mathrm{~g} / \mathrm{L}$ sodium pyruvate, and $20 \%$ FBS (Gibco). SCC-25 cells were maintained in a 1:1 mixture of 90\% DMEM (Gibco) and Ham's F12 medium (Gibco) containing $1.2 \mathrm{~g} / \mathrm{L}$ sodium bicarbonate, $2.5 \mathrm{mM}$ L-glutamine, $15 \mathrm{mM}$ HEPES, and $0.5 \mathrm{mM}$ sodium pyruvate, and supplemented with $400 \mathrm{ng} / \mathrm{mL}$ hydrocortisone as well as $10 \%$ FBS. All cells were maintained in a humid incubator at $37^{\circ} \mathrm{C}$ with $5 \% \mathrm{CO}_{2}$. The use of the cell lines in this experiment was approved by the Chinese Academy of Sciences (Shanghi, China) (no. 2017-021-01).

\section{Treatment of Tca-8I I 3 cells and SCC- 25 cells}

Allicin was bought from Sigma (St Louis, MO, USA). After weighing, allicin was dissolved to the desired concentration in DMSO, and the final concentration of ethanol in the culture medium was $0.1 \%$. According to several previous studies, the concentration of allicin was $50 \mu \mathrm{g} /$ $\mathrm{mL}$, and the concentrations were multiplied or divided exponentially by $2 .^{10,11}$ Therefore, Tca- 8113 cells and SCC-25 cells were treated with non-stimulated control, $12.5 \mu \mathrm{g} / \mathrm{mL}$ allicin, $25 \mu \mathrm{g} / \mathrm{mL}$ allicin, $50 \mu \mathrm{g} / \mathrm{mL}$ allicin, and $40 \mu \mathrm{g} / \mathrm{mL}$ cis-platinum, which were divided into five groups and labeled as blank control, allicin $12.5 \mu \mathrm{g} / \mathrm{mL}$, allicin $25 \mu \mathrm{g} / \mathrm{mL}$, allicin $50 \mu \mathrm{g} / \mathrm{mL}$, and cis-platinum $40 \mu \mathrm{g} / \mathrm{mL}$ groups, respectively. Cell proliferation was determined by the Cell Counting Kit-8 (CCK-8) (Abcam, Cambridge, MA, USA) assay at 0, 24, and 48 hours. The cell apoptosis rate was detected by an annexin V (AV) apoptosis detection kit with propidium iodide (PI) (Invitrogen, Thermo Fisher Scientific, Waltham, MA, USA) at the time-point of 48 hours. Pro-apoptotic proteins and anti-apoptotic protein expression, including Bax, Bcl2 , C-Caspase 3 , and $\beta$-actin, were evaluated by Western blot assay at 48 hours.

\section{CCK-8 assay}

Cells were seeded in 96-well tissue culture plates at a density of $3 \times 10^{4}$ cells per well. Cells were added to 90 $\mu \mathrm{L}$ medium supplemented with $10 \mu \mathrm{L}$ CCK-8, and then incubated at $37^{\circ} \mathrm{C}$ with $5 \% \mathrm{CO}_{2}$. The cell proliferation ability was represented by the optical density (OD), which was detected using a microplate reader (BioTek, Winooski, VT, USA). The cellular inhibition rate was computed by the following formula: Cellular inhibition rate $=\left(\mathrm{OD}_{\text {Blank control }}\right.$ - OD Experimental group)/OD Blank control.

\section{$\mathrm{AV} / \mathrm{PI}$ assay}

After digestion, washing, and collection, cells were suspended in $100 \mu \mathrm{L}$ binding buffer supplemented with $2 \mu \mathrm{L}$ AV (Invitrogen) and incubated at room temperature for 15 minutes in the dark. Subsequently, $2 \mu \mathrm{L}$ PI (Invitrogen) was added to the cell suspension and incubated for 5 
minutes. Apoptotic cells were detected and analyzed by flow cytometry (BD FACSVerse ${ }^{\mathrm{TM}}$; BD Biosciences, Heidelberg, Germany).

\section{Western blot}

Cells were seeded in six-well tissue culture plates at a density of $2 \times 10^{5}$ cells per well. Cells were lysed using a radio-immunoprecipitation assay (RIPA buffer) (Thermo Fisher Scientific) supplemented with $1 \%$ protease inhibitor cocktail as well as $1 \%$ phenylmethanesulfonyl fluoride, and then centrifuged. Subsequently, the concentration of the protein samples was measured by a Pierce BCA Protein Assay Kit (Pierce Biotechnology, Thermo Scientific, Rockford, IL, USA). Then, the protein samples were separated by SDS-PAGE and transferred to polyvinylidene fluoride (PVDF) membranes (Millipore, Billerica, MA, USA). The PVDF membranes were blocked with skim milk at room temperature for 2 hours, and incubated with primary antibodies including Bax, BCL-2, C-Caspase 3, and $\beta$-actin (Cell Signaling Technology, Danvers, MA, USA). Following this, the PVDF membranes were incubated with the horseradish peroxidase-conjugated secondary antibody (Cell Signaling Technology) and finally visualized by an ECL advanced Western Blotting Detection Kit (GE Healthcare, Piscataway, NJ, USA). Western blot images were quantified according to the following steps: after obtaining the gray level of indicated proteins by the ChemiDocTM MP imaging system, the gray value of indicated protein was computed as: Gray value = Gray level of indicated protein/ Gray level of corresponding $\beta$-actin. All experiments were independently repeated three times. The detailed information and catalogue numbers for BAX, BCL-2, CASP3, and $\beta$-actin antibodies are as follows: Bax (D2E11) rabbit monoclonal antibody (mAb) \#5023; Bcl-2 (D55G8) rabbit mAb (human specific) \#4223; cleaved Caspase-3 (Asp175) (5A1E) rabbit mAb \#9664; Caspase-3 (D3R6Y) rabbit $\mathrm{mAb} \# 14,220$; and $\beta$-actin (13E5) rabbit mAb \#4970.

\section{Statistics}

All experiments were independently performed three times. SPSS version 21.0 (IBM Corp., Armonk, NY, USA) and GraphPad Prism 5.01 (GraphPad Software, La Jolla, CA, USA) were used for statistical analysis. Data are shown as mean \pm standard error. Comparisons between two groups were made using the independent sample $t$-test. $p<0.05$ was considered significant.

\section{Results}

\section{Effect of allicin on cell proliferation and cell apoptosis rate in Tca-8I I 3 cells and SCC- 25 cells}

In Tac-8113 cells, cell proliferation was inhibited by $40 \mu \mathrm{g} /$ $\mathrm{mL}$ cis-platinum ( $p=0.025), 25 \mu \mathrm{g} / \mathrm{mL}$ allicin $(p=0.018)$, and $50 \mu \mathrm{g} / \mathrm{mL}$ allicin $(p=0.012)$ at 24 hours, and repressed by 40 $\mu \mathrm{g} / \mathrm{mL} \quad$ cis-platinum $\quad(p=0.009), \quad 12.5 \mu \mathrm{g} / \mathrm{mL} \quad$ allicin ( $p=0.035$ ), $25 \mu \mathrm{g} / \mathrm{mL}$ allicin $(p=0.008)$, and $50 \mu \mathrm{g} / \mathrm{mL}$ allicin $(p=0.007)$ at 48 hours compared to the blank control. In addition, cell proliferation was suppressed by $50 \mu \mathrm{g} / \mathrm{mL}$ allicin compared to $40 \mu \mathrm{g} / \mathrm{mL}$ cis-platinum at 48 hours $(p=0.044)$ (Figure 1A). The cell proliferation inhibition rate after treatment with $40 \mu \mathrm{g} / \mathrm{mL}$ cis-platinum, $12.5 \mu \mathrm{g} / \mathrm{mL}$ allicin, $25 \mu \mathrm{g} / \mathrm{mL}$ allicin, and $50 \mu \mathrm{g} / \mathrm{mL}$ allicin was 26.2 $\pm 5.38 \%, 16.5 \pm 2.2 \%, 22.7 \pm 3.9 \%$, and $35.4 \pm 2.6 \%$, respectively, at 24 hours, and $38.4 \pm 3.6 \%, 24.3 \pm 1.8 \%, 36.3 \pm 2.0 \%$, and $51.5 \pm 1.4 \%$, respectively, at 48 hours (Figure 1B). Compared to the $40 \mu \mathrm{g} / \mathrm{mL}$ cis-platinum group (38.4 $\pm 3.6 \%$ ), the cell proliferation inhibition rate was higher in the $50 \mu \mathrm{g} / \mathrm{mL}$ allicin group $(51.5 \pm 1.4 \%)$ at 48 hours $(p=0.032)$. Apoptotic cells were detected and analyzed by flow cytometry, which revealed that cell apoptosis was increased in the $40 \mu \mathrm{g} / \mathrm{mL}$ cis-platinum ( $p<0.001), 12.5 \mu \mathrm{g} /$ $\mathrm{mL}$ allicin $(p=0.003), 25 \mu \mathrm{g} / \mathrm{mL}$ allicin $(p<0.001)$, and $50 \mu \mathrm{g} /$ $\mathrm{mL}$ allicin $(p<0.001)$ groups compared to the blank control group at 48 hours (Figure 1C, D). Compared to the $40 \mu \mathrm{g} / \mathrm{mL}$ cis-platinum group, cell apoptosis was decreased in the 12.5 $\mu \mathrm{g} / \mathrm{mL}$ allicin group ( $p=0.005$ ) but increased in the $50 \mu \mathrm{g} / \mathrm{mL}$ allicin group $(p=0.033)$ (Figure 1C, D). In SCC- 25 cells, cell proliferation was inhibited by $40 \mu \mathrm{g} / \mathrm{mL}$ cis-platinum ( $p=0.022$ ), $25 \mu \mathrm{g} / \mathrm{mL}$ allicin $(p=0.020$ ), and $50 \mu \mathrm{g} / \mathrm{mL}$ allicin ( $p=0.009$ ) at 24 hours, and reduced by $40 \mu \mathrm{g} / \mathrm{mL}$ cisplatinum $(p<0.001), 25 \mu \mathrm{g} / \mathrm{mL}$ allicin $(p=0.006)$, and $50 \mu \mathrm{g} /$ $\mathrm{mL}$ allicin $(p<0.001)$ at 48 hours compared to the blank control. Also, cell proliferation was enhanced by $12.5 \mu \mathrm{g} /$ $\mathrm{mL}$ allicin $(p=0.039)$ and suppressed by $50 \mu \mathrm{g} / \mathrm{mL}$ allicin ( $p=0.005$ ) compared to $40 \mu \mathrm{g} / \mathrm{mL}$ cis-platinum at 48 hours (Figure 1E). In addition, cell apoptosis was stimulated in the $40 \mu \mathrm{g} / \mathrm{mL}$ cis-platinum $(p<0.001), 12.5 \mu \mathrm{g} / \mathrm{mL}$ allicin ( $p=0.002), 25 \mu \mathrm{g} / \mathrm{mL}$ allicin $(p<0.001)$, and $50 \mu \mathrm{g} / \mathrm{mL}$ allicin $(p<0.001)$ groups compared with the blank control group at 48 hours (Figure 1F, G). Compared with the $40 \mu \mathrm{g} / \mathrm{mL}$ cisplatinum group, cell apoptosis was repressed in the $12.5 \mu \mathrm{g} /$ $\mathrm{mL}$ allicin group $(p=0.004$ ) (Figure $1 \mathrm{~F}, \mathrm{G})$. Together, these results indicate that allicin hindered cell proliferation and induced cell apoptosis, and $50 \mu \mathrm{g} / \mathrm{mL}$ allicin was more 
A

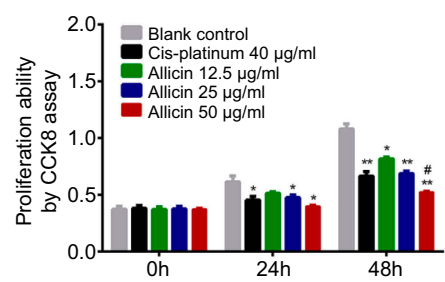

D
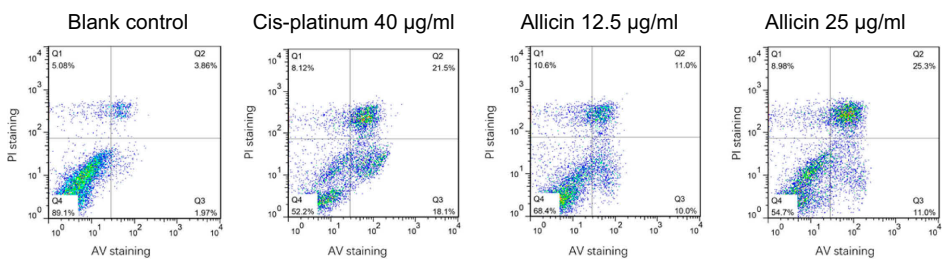

C
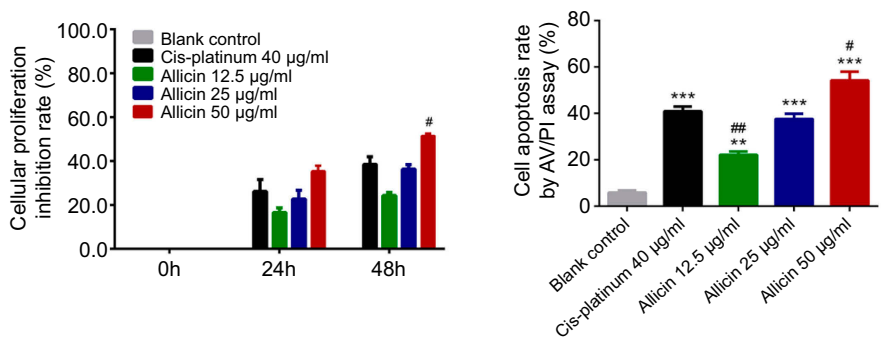

Allicin $50 \mu \mathrm{g} / \mathrm{ml}$

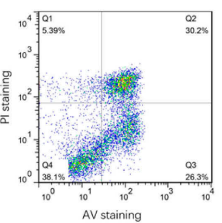

E

F

SCC-25 cells

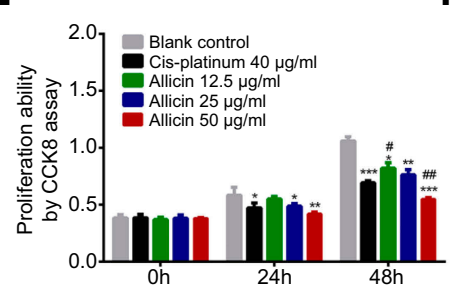

G

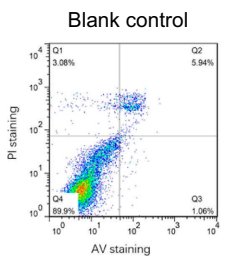

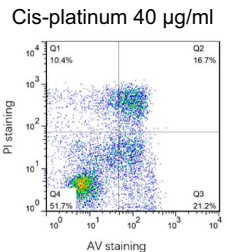
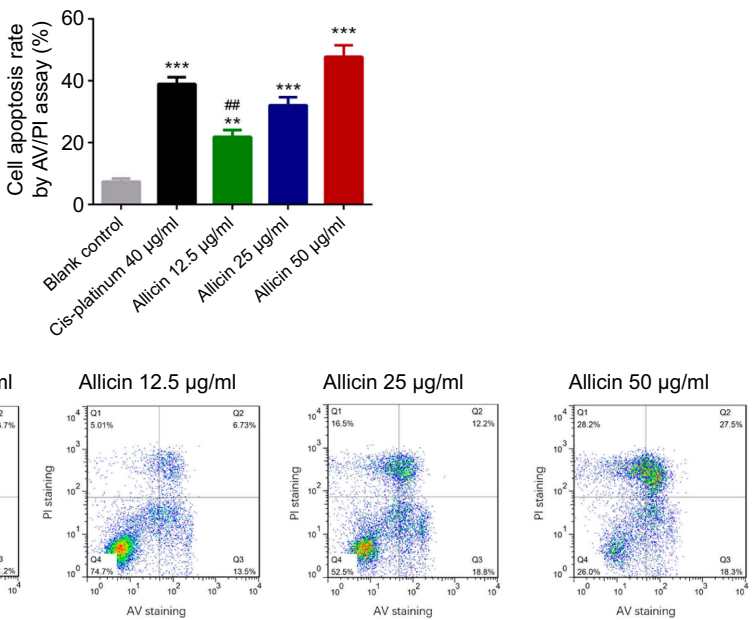

Figure I Effect of allicin on cell proliferation and cell apoptosis rate in Tca-8II 3 cells and SCC-25 cells. (A) Cell proliferation ability after treatment with $0 \mu$ g/mL allicin, $12.5 \mu \mathrm{g} / \mathrm{mL}$ allicin, $25 \mu \mathrm{g} / \mathrm{mL}$ allicin, $50 \mu \mathrm{g} / \mathrm{mL}$ allicin, and $40 \mu \mathrm{g} / \mathrm{mL}$ cis-platinum at 0,24 , and 48 hours in Tca-8I I 3 cells. (B) Cell proliferation inhibition rate after incubation with $0 \mu \mathrm{g} / \mathrm{mL}$ allicin, $12.5 \mu \mathrm{g} / \mathrm{mL}$ allicin, $25 \mu \mathrm{g} / \mathrm{mL}$ allicin, $50 \mu \mathrm{g} / \mathrm{mL}$ allicin, and $40 \mu \mathrm{g} / \mathrm{mL}$ cis-platinum at 0,24 , and 48 hours in Tca-8I I 3 cells. (C and D) Cell apoptosis rate after incubation with $0 \mu \mathrm{g} / \mathrm{mL}$ allicin, $12.5 \mu \mathrm{g} / \mathrm{mL}$ allicin, $25 \mu \mathrm{g} / \mathrm{mL}$ allicin, $50 \mu \mathrm{g} / \mathrm{mL}$ allicin, and $40 \mu \mathrm{g} / \mathrm{mL}$ cis-platinum at 48 hours in Tca-8II 3 cells. (E) Cell proliferation ability after treatment with $0 \mu \mathrm{g} / \mathrm{mL}$ allicin, $12.5 \mu \mathrm{g} / \mathrm{mL}$ allicin, $25 \mu \mathrm{g} / \mathrm{mL}$ allicin, $50 \mu \mathrm{g} / \mathrm{mL}$ allicin, and $40 \mu \mathrm{g} / \mathrm{mL}$ cis-platinum at 0,24 , and 48 hours in SCC-25 cells. (F and $\mathbf{G}$ ) Cell apoptosis rate after incubation with $0 \mu \mathrm{g} / \mathrm{mL}$ allicin, $12.5 \mu \mathrm{g} / \mathrm{mL}$ allicin, $25 \mu \mathrm{g} / \mathrm{mL}$ allicin, $50 \mu \mathrm{g} / \mathrm{mL}$ allicin, and $40 \mu \mathrm{g} / \mathrm{mL}$ cis-platinum at 48 hours in SCC-25 cells. The comparison between any two groups was determined by independent sample $t$-test. *Comparison between the blank control group and experimental groups; ${ }^{*}$ comparison between the $40 \mu \mathrm{g} / \mathrm{mL}$ cis-platinum group and allicin groups. ${ }^{*} p<0.05,{ }_{p} p<0.05,{ }^{* *} p<0.01,{ }^{\#} p<0.01,{ }^{*} * * p<0.001$.

Abbreviations: CCK8, Cell Counting Kit-8; AV, annexin V; PI, propidium iodide.

effective in reducing cell proliferation and triggering apoptosis than $40 \mu \mathrm{g} / \mathrm{mL}$ cis-platinum in both Tca-8113 cells and SCC-25 cells.

\section{Effect of allicin on cell proliferation in HUVEC cells}

Further validation was performed in a normal oral cell line. Compared to the lank control, cell proliferation was inhibited by $40 \mu \mathrm{g} / \mathrm{mL}$ cis-platinum $(p=0.027)$ at 24 hours and hindered by $40 \mu \mathrm{g} / \mathrm{mL}$ cis-platinum ( $p=0.002), 25 \mu \mathrm{g} /$ $\mathrm{mL}$ allicin $(p=0.019)$, and $50 \mu \mathrm{g} / \mathrm{mL}$ allicin $(p=0.011)$ at 48 hours. Also, cell proliferation ability was increased in the $12.5 \mu \mathrm{g} / \mathrm{mL}$ allicin group compared with the $40 \mu \mathrm{g} / \mathrm{mL}$ cis-platinum group $(p=0.037)$ at 24 hours (Figure $2 \mathrm{~A}$ ). In addition, the cell proliferation inhibition rate was decreased in the $12.5 \mu \mathrm{g} / \mathrm{mL}$ allicin $(p=0.021), 25 \mu \mathrm{g} / \mathrm{mL}$ allicin $(p=0.029)$, and $50 \mu \mathrm{g} / \mathrm{mL}$ allicin $(p=0.022)$ groups compared to the $40 \mu \mathrm{g} / \mathrm{mL}$ cis-platinum group at 24 hours, 

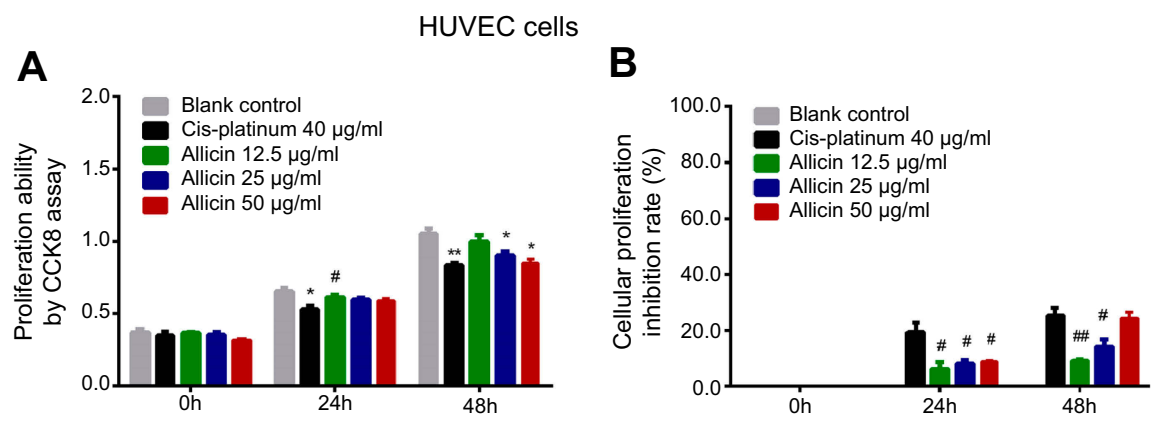

Figure 2 Impact of allicin on cell proliferation in HUVEC cells. (A) Cell proliferation ability after treatment with $0 \mu \mathrm{g} / \mathrm{mL}$ allicin, $12.5 \mu \mathrm{g} / \mathrm{mL}$ allicin, $25 \mu \mathrm{g} / \mathrm{mL}$ allicin, $50 \mu \mathrm{g} / \mathrm{mL}$ allicin, and $40 \mu \mathrm{g} / \mathrm{mL}$ cis-platinum at 0,24 , and 48 hours. (B) Cell proliferation inhibition rate after treatment with $0 \mu \mathrm{g} / \mathrm{mL}$ allicin, $12.5 \mu \mathrm{g} / \mathrm{mL}$ allicin, $25 \mu \mathrm{g} / \mathrm{mL}$ allicin, $50 \mu \mathrm{g} /$ $\mathrm{mL}$ allicin, and $40 \mu \mathrm{g} / \mathrm{mL}$ cis-platinum at 0,24 , and 48 hours. The comparison between any two groups was determined by independent sample $t$-test. $*$ Comparison between the blank control group and experimental groups; ${ }^{\#}$ comparison between the $40 \mu \mathrm{g} / \mathrm{mL}$ cis-platinum group and allicin groups. ${ }^{*} p<0.05,{ }^{\#} p<0.05,{ }^{* *} p<0.01$, ${ }^{\# \#} p<0.01$. Abbreviation: CCK8, Cell Counting Kit-8.

and in the $12.5 \mu \mathrm{g} / \mathrm{mL}$ allicin $(p=0.004)$ and $25 \mu \mathrm{g} / \mathrm{mL}$ allicin $(p=0.042)$ groups at 48 hours (Figure 2B).

\section{Effect of allicin on apoptosis markers in Tca-8I I 3 cells}

Compared to the blank control group, expression of the proapoptosis protein Bax (Figure 3A, B) and C-Caspase 3 (Figure 3A, 3D) was elevated in $40 \mu \mathrm{g} / \mathrm{mL}$ cis-platinum ( $p=0.005$ for Bax and $p=0.004$ for C-Caspase 3), $12.5 \mu \mathrm{g} / \mathrm{mL}$ allicin $(p<0.001$ for Bax and C-Caspase 3), $25 \mu \mathrm{g} / \mathrm{mL}$ allicin $(p<0.001$ for Bax and C-Caspase 3), and $50 \mu \mathrm{g} / \mathrm{mL}$ allicin groups ( $p<0.001$ for Bax and $p=0.006$ for $\mathrm{C}$-Caspase 3 ), while expression of the apoptosis-inhibitory protein $\mathrm{Bcl}-2$ (Figure 3A, C) was reduced in $40 \mu \mathrm{g} / \mathrm{mL}$ cis-platinum $(p=0.027), 12.5 \mu \mathrm{g} / \mathrm{mL}$ allicin $(p=0.041), 25 \mu \mathrm{g} / \mathrm{mL}$ allicin $(p<0.001)$, and $50 \mu \mathrm{g} / \mathrm{mL}$ allicin $(p=0.007)$ groups at 48 hours. Bax expression was higher in the $12.5 \mu \mathrm{g} / \mathrm{mL}$ allicin $(p=0.001), 25 \mu \mathrm{g} / \mathrm{mL}$ allicin $(p<0.001)$ and $50 \mu \mathrm{g} / \mathrm{mL}$ allicin ( $p=0.049$ ) groups compared to the $40 \mu \mathrm{g} / \mathrm{mL}$ cis-platinum group (Figure 3B). C-Caspase 3 expression was also increased in the $12.5 \mu \mathrm{g} / \mathrm{mL}$ allicin $(p=0.002)$ and $25 \mu \mathrm{g} / \mathrm{mL}$ allicin ( $p=0.002$ ) groups compared with the $40 \mu \mathrm{g} / \mathrm{mL}$ cis-platinum group (Figure 3D). Bcl-2 expression declined in both the 25 $\mu \mathrm{g} / \mathrm{mL}$ allicin $(p=0.003)$ and $50 \mu \mathrm{g} / \mathrm{mL}$ allicin $(p=0.021)$ groups compared to the $40 \mu \mathrm{g} / \mathrm{mL}$ cis-platinum group (Figure 3C). Hence, allicin promoted pro-apoptotic proteins but inhibited anti-apoptotic protein, and $50 \mu \mathrm{g} / \mathrm{mL}$ allicin was more effective than $40 \mu \mathrm{g} / \mathrm{mL}$ cis-platinum in elevating proapoptotic proteins in Tca-8113 cells.

\section{Discussion}

In this study, we found that 1) allicin inhibited cell proliferation and promoted cell apoptosis in OTSCC cells; and 2) $50 \mu \mathrm{g} / \mathrm{mL}$ allicin more effectively repressed cell proliferation and triggered cell apoptosis compared to $40 \mu \mathrm{g} / \mathrm{mL}$ cis-platinum in OTSCC cells.

OTSCC, one of the most common subgroups of oral cancers, is related to modifiable behaviors (including frequent tobacco use and excessive alcohol consumption), chronic infections caused by fungi, bacteria, or viruses (due to poor oral hygiene, ill-fitting dentures, and other rough surfaces on the teeth), and poor nutrition. ${ }^{4}$ Surgery is commonly recommended as treatment for tumor removal in patients with OTSCC in the early stage, while for advanced-stage OTSCC patients who may not be able to undergo surgery, various therapies (including chemotherapy, radiotherapy, and targeted therapy) have been widely used. Despite improvements in the management of disease in the past few decades, there are still some adverse effects and drug resistance caused by the different therapies, leading to poorer treatment outcomes in OTSCC patients. ${ }^{5,12}$ Therefore, the discovery of other therapeutics for OTSCC is necessary to improve treatment outcomes in OTSCC patients.

Allicin is a major ingredient of crushed garlic in traditional medicine. It has multiple pharmacological effects and contributes to a wide spectrum of anti-cancer activities. For instance, allicin hinders cell proliferation in colon cancer cells by depleting the intracellular glutathione level. ${ }^{8}$ Allicin also triggers apoptosis in gastric carcinoma cells through the p38 mitogen-activated protein kinase/ caspase-3 signaling pathway. ${ }^{13}$ Moreover, allicin enhances cell apoptosis in human renal clear cell carcinoma cells by suppressing the hypoxia-inducible factor-1 $\alpha$ pathway. ${ }^{9}$ Therefore, these previous discoveries suggest that allicin has a good effect in killing cancer cells and controlling tumor growth in various carcinomas, particularly in digestive cancer. However, limited information was found on 
Tca-8113 cells
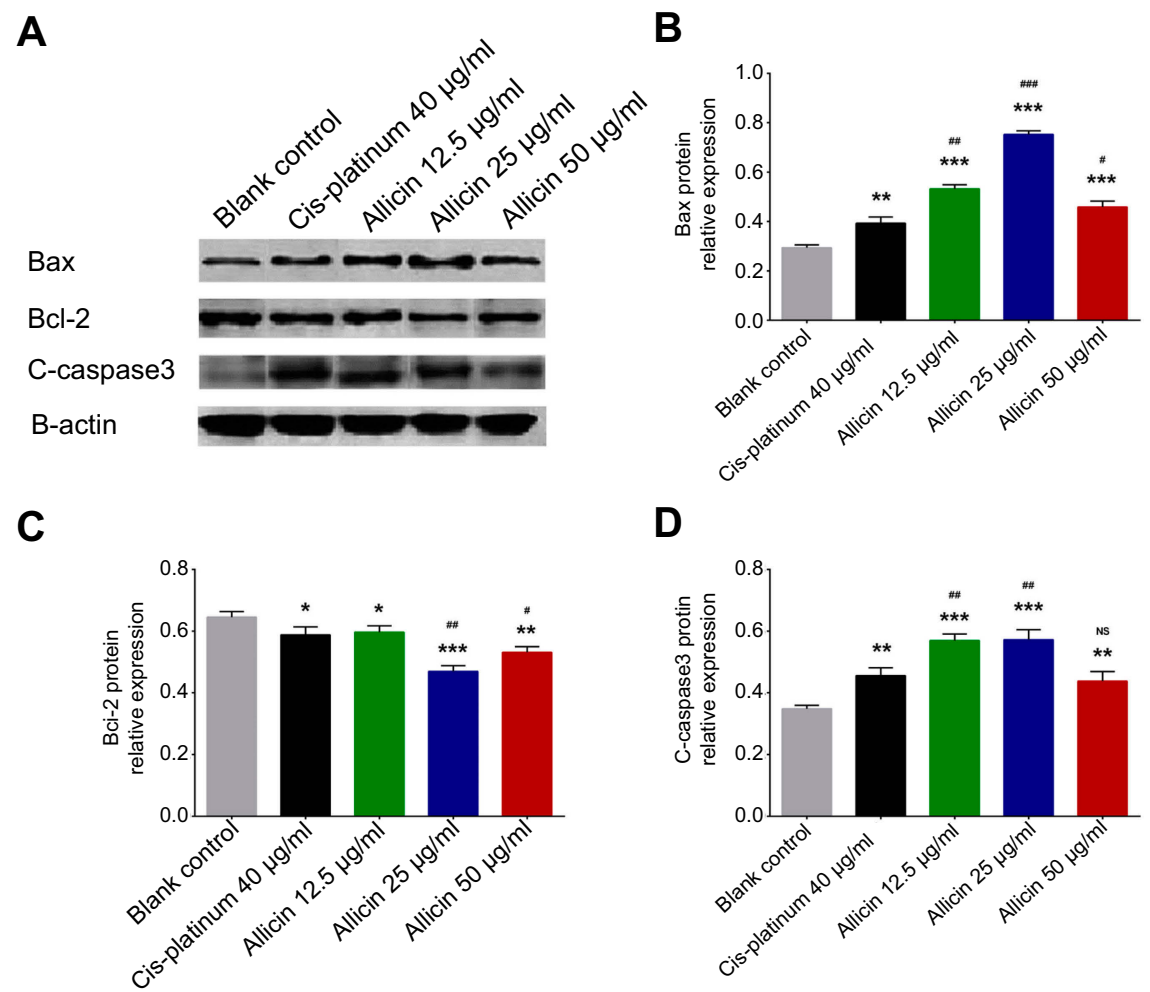

Figure 3 Effects of allicin on pro-apoptotic proteins and anti-apoptotic protein in Tca-8II3 cells. (A) Bax, Bcl-2, C-Caspase 3, and $\boldsymbol{\beta}$-actin expression was detected by Western blot after treatment with allicin or cis-platinum for 48 hours. (B) Bax protein relative expression. (C) Bcl-2 protein relative expression. (D) C-Caspase 3 protein relative expression. The comparison between any two groups was determined by independent sample t-test. $*$ Comparison between the blank control group and experimental groups; ${ }^{\#}$ comparison between the $40 \mu \mathrm{g} / \mathrm{mL}$ cis-platinum group and allicin groups. ${ }^{*} p<0.05,{ }^{*} p<0.05,{ }^{* *} p<0.01,{ }^{\# \#} p<0.01,{ }^{* * *} p<0.001,{ }^{\# \#} p<0.001$.

the effect of allicin on OTSCC cells, with just one previous study demonstrating that allicin has cytotoxic effects on cell line SCC-15. ${ }^{11}$ Considering that, in the previous study, ${ }^{11}$ there was only one human tongue squamous carcinoma cell line (SCC-15), there was no positive control, and the assessment of apoptosis was performed using a single test, there is a great need for additional study with more cancer cell lines and multiple tests. In the present experiment, we used two human tongue squamous carcinoma cell lines (Tca-8113 cells and SCC-25 cells) with multiple tests to explore the effect of allicin on cell proliferation and apoptosis compared to a blank control and cis-platinum in OTSCC, and we observed that allicin inhibited cell proliferation and promoted cell apoptosis in OTSCC. To verify the effect of allicin in OTSCC, in vitro experiments were repeated in another OTSCC cell line (SCC-25 cells), and similar results were also observed, indicating that allicin may be a novel and effective compound for the treatment of OTSCC, by inhibiting cancer progression and improving treatment outcomes through its effects on cell proliferation and apoptosis.
Cis-platinum is a common chemotherapy drug, which was approved by the US Food and Drug Administration in 1978, and has great benefits in reducing tumor growth and inhibiting distant metastasis to control disease progression and improve prognosis in patients with carcinomas, including OTSCC. ${ }^{14}$ However, a proportion of OTSCC patients still experiences adverse effects caused by cis-platinum, including pain, nausea, and vomiting, which directly decrease their quality of life and worsen therapeutic outcomes. In addition, the majority of OTSCC patients after longterm or large-dose cis-platinum treatment will gradually develop acquired chemoresistance, leading to poor therapeutic outcomes, high recurrence rates, or even death. ${ }^{14,15}$ Although several studies have demonstrated the role of cis-platinum in OTSCC, few studies have compared the efficacy of cis-platinum and other drug compounds in OTSCC. In the current study, we carried out cell assays to compare the effects of allicin and cisplatinum on cell proliferation and apoptosis in OTSCC cells, and found that $50 \mu \mathrm{g} / \mathrm{mL}$ allicin was more 
effective in repressing cell proliferation and promoting cell apoptosis compared to $40 \mu \mathrm{g} / \mathrm{mL}$ cis-platinum, suggesting that high-dose allicin may be more effective than cis-platinum in the treatment of OTSCC patients. Taking all the results together, this experiment may not only provide a more solid foundation for the effect of allicin in killing tumor cells, but also offer additional evidence for the effect of allicin on normal cells, thereby providing a convincing perspective for the clinical application of allicin in the future.

\section{Conclusion}

Allicin has good efficacy in repressing cell proliferation as well as facilitating cell apoptosis in OTSCC.

\section{Disclosure}

The authors report no conflicts of interest in this work.

\section{References}

1. Bray F, Ferlay J, Soerjomataram I, Siegel RL, Torre LA, Jemal A. Global cancer statistics 2018: GLOBOCAN estimates of incidence and mortality worldwide for 36 cancers in 185 countries. CA Cancer J Clin. 2018;68(6):394-424.

2. Almangush A, Heikkinen I, Makitie AA, et al. Prognostic biomarkers for oral tongue squamous cell carcinoma: a systematic review and meta-analysis. $\quad B r \quad J$ Cancer. 2017;117(6):856-866. doi:10.1038/ bjc.2017.244

3. Ng JH, Iyer NG, Tan MH, Edgren G. Changing epidemiology of oral squamous cell carcinoma of the tongue: a global study. Head Neck. 2017;39(2):297-304. doi:10.1002/hed.24589

4. Srinivasprasad V, Dineshshankar J, Sathiyajeeva J, Karthikeyan M, Sunitha J, Ragunathan R. Liaison between micro-organisms and oral cancer. J Pharm Bioallied Sci. 2015;7(Suppl 2):S354-60. doi:10.4103/ 0975-7406.163451
5. Chen B, Xue J, Meng X, Slutzky JL, Calvert AE, Chicoine LG. Resveratrol prevents hypoxia-induced arginase II expression and proliferation of human pulmonary artery smooth muscle cells via Akt-dependent signaling. Am J Physiol Lung Cell Mol Physiol. 2014;307(4):L317-25. doi:10.1152/ajplung.00285.2013

6. Shuang C, Weiguang Y, Zhenkun F, et al. Toll-like receptor 5 gene polymorphism is associated with breast cancer susceptibility. Oncotarget. 2017;8(51):88622-88629. doi:10.18632/oncotarget.20242

7. Cha JH, Choi YJ, Cha SH, Choi CH, Cho WH. Allicin inhibits cell growth and induces apoptosis in U87MG human glioblastoma cells through an ERK-dependent pathway. Oncol Rep. 2012;28(1):41-48. doi:10.3892/or.2012.1910

8. Hirsch K, Danilenko M, Giat J, et al. Effect of purified allicin, the major ingredient of freshly crushed garlic, on cancer cell proliferation. Nutr Cancer. 2000;38(2):245-254. doi:10.1207/S15327914NC382_14

9. Song B, Shu Y, Cui T, Fu P. Allicin inhibits human renal clear cell carcinoma progression via suppressing HIF pathway. Int J Clin Exp Med. 2015;8(11):20573-20580.

10. Zhang Q, Yang D. Allicin suppresses the migration and invasion in cervical cancer cells mainly by inhibiting NRF2. Exp Ther Med. 2019;17(3):1523-1528. doi:10.3892/etm.2019.7348

11. Szychowski KA, Binduga UE, Rybczynska-Tkaczyk K, Leja ML, Gminski J. Cytotoxic effects of two extracts from garlic (Allium sativum L.) cultivars on the human squamous carcinoma cell line SCC-15. Saudi J Biol Sci. 2018;25(8):1703-1712. doi:10.1016/j. sjbs.2016.10.005

12. Su YY, Chen CH, Chien CY, Lin WC, Huang WT, Li SH. Mitochondrial assembly receptor expression is an independent prognosticator for patients with oral tongue squamous cell carcinoma. $J$ Renin Angiotensin Aldosterone Syst. 2017;18(3):1470320317717904. doi:10.1177/ 1470320317717904

13. Zhang X, Zhu Y, Duan W, Feng C, He X. Allicin induces apoptosis of the MGC-803 human gastric carcinoma cell line through the p38 mitogen-activated protein kinase/caspase-3 signaling pathway. Mol Med Rep. 2015;11(4):2755-2760. doi:10.3892/mmr.2014.3109

14. Gibson MK, Li Y, Murphy B, et al. Randomized phase III evaluation of cisplatin plus fluorouracil versus cisplatin plus paclitaxel in advanced head and neck cancer (E1395): an intergroup trial of the Eastern cooperative oncology group. J Clin Oncol. 2005;23 (15):3562-3567. doi:10.1200/JCO.2005.01.057

15. Galluzzi L, Senovilla L, Vitale I, et al. Molecular mechanisms of cisplatin resistance. Oncogene. 2012;31(15):1869-1883. doi:10.1038/ onc.2011.627
OncoTargets and Therapy

\section{Publish your work in this journal}

OncoTargets and Therapy is an international, peer-reviewed, open access journal focusing on the pathological basis of all cancers, potential targets for therapy and treatment protocols employed to improve the management of cancer patients. The journal also focuses on the impact of management programs and new therapeutic agents and protocols on patient perspectives such as quality of life, adherence and satisfaction. The manuscript management system is completely online and includes a very quick and fair peer-review system, which is all easy to use. Visit http://www.dovepress.com/ testimonials.php to read real quotes from published authors. 